\title{
COLORIMETRIC MEASUREMENTS OF VEGETABLE OILS BY SMARTPHONE-BASED IMAGE ANALYSIS
}

\author{
Sanita Vucāne\#, Ingmars Cinkmanis, and Mārtinš Šabovics \\ Faculty of Food Technology, Latvia University of Life Sciences and Technologies, 22 Rīgas Str., Jelgava, LV-3004, LATVIA \\ \# Corresponding author, sanitavucane@ inbox.lv
}

Communicated by Sandra Muižniece-Brasava

\begin{abstract}
One of the most important indicators of quality of vegetable oils is colour, which can be detected with colorimetric measurements. The determination of colour is traditionally done using colorimeters, spectrometers, tintometers, and other analytical equipment. As an alternative to replace the classical analytical methods, smartphone-based colorimetry using digital image analysis can be used. For colorimetric detection of colour in vegetable oils, a Huawei P30 lite smartphone and android application "Colour Picker" with an image matching algorithm RGB model was used. The image of sample and standard solutions was captured in a polyvinyl chloride box with lightemitting diode (LED) lamps. The aim of the study was to detect the colour of vegetable oils with smartphone-based image analysis. The detected colour of eleven vegetable oils (sea buckthorn, sunflower, rice, macadamia nut, hemp, corn, grape, linseed, rapeseed, olive, and milk thistle oils) was compared with standard solutions of iodine with a concentration range from 0 to $100 \mathrm{mg} \cdot 100$ $\mathrm{ml}^{-1}$. The results show that smartphone-based colorimetry can be used for detection of the colour of vegetable oils and it is possible to compare the colour with standard solutions of iodine. The colour of vegetable oils was expressed as the colour number obtained from an iodine standard solution prepared in deionised water.
\end{abstract}

Keywords: colour, digital image colorimetry, Android, Huawei, vegetable fats.

\section{INTRODUCTION}

Since the end of the 1990s, vegetable oils and their daily use in human life have been intensively studied around the world. Fresh and unrefined vegetable oils, which are considered as functional foods, were analysed (Ernster and Dallner, 1995). Vegetable oils are obtained from fruits or seeds. They contain on average $99.0 \%$ fat and $0.2 \%$ water. Vegetable oils contain mainly fatty acids and are one of the nutrients needed for the human body to function successfully (Frančáková et al., 2015). Besides fatty acids, biological active components like carotenoids and chlorophylls are also important for human health. Carotenoids are isoprenoids, consisting of eight isoprene units and in nature they are the basic source of yellow, orange and red pigments. According to the literature, the most studied carotenoids are $\beta$-carotene, however, other carotenoids like lycopene, lutein, and $\beta$-cryptoxanthin are also found in vegetable oils (Fakourelis et al., 1987; Moreau et al., 2007). Carotenoids are not only precursors of vitamin A provitamins and antioxidants, but they inhibit the formation of pathological substances in cells and are used in cancer therapy and reducing chronic conditions related to coronary heart disease (Anguelova and Warthesen, 2000; Huang et al., 2003; Prakash and Gupta, 2014). Chlorophyll is composed of a porphyrin or chlorin ring system with a magnesium ion in a central position and it is a unique green pigment found in plants and cyanobacteria (Pareek et al., 2017). Chlorophyll has positive effects on human health by stimulating the immune system, cleaning of toxins in humans and intestines, and they are used in cancer therapy, to normalise blood pressure, detoxify the liver, and against skin rashes, sinusitis, fluid build-up and other health diseases (Inanc, 2011). Therefore, it is important to study these pigments in vegetable oils. Colorimetry is method for determination of coloured compounds in solution by measuring the relative absorption of visible light. A colorimeter or tintometer is traditionally used for analytical measurements of colours. This analytical equipment determines concentrations in solution by the Beer-Lambert law — the concentration of a solute is proportional to the absorbance (Narayana et al., 2016). With the development of computer science 
and nanotechnology, smartphones can be used as a substitute for traditional analytical equipment. Like in colorimetry, using an iOS operating system app algorithm and good resolution cameras, smartphones can absorb the light spectra in accordance with the Beer-Lambert's law (Anderson et al., 2004). Smartphone-based analysis is used in several fields of science: point-of-Care technologies (Vashist and Luong, 2019), chemical analysis (Zhu et al., 2011, Bueno et al., 2015; Masawat et al., 2015; Levin et al., 2016, Vucane et al., 2020), food allergens (Coskun et al., 2013; Ozcan et al., 2013), biosensors (Roda et al., 2016; Zhang and Liu, 2016), Escherichia coli (Zhu et al., 2012), fruit ripeness (Das et al., 2016), paper-based strips (Yetisen et al., 2014), and dermatology (Kroemer et al., 2011). In nature, the primary colours are red $(\mathrm{R})$, green $(\mathrm{G})$ and blue (B), which form the RGB colour model for describing the visible light seen by the human eye. Visible light can be digitally described in pixels ranging from 0 to 255 (Rhyne, 2016). The RGB model system can be used in smartphonebased colorimetry for the determination of colours. The advantage of a smartphone over classical analytical methods is its ease of use, mobility and device with low-cost. Highresolution cameras, and ultra-high sensitive optical and light sensors in smartphones allow to make measurements in accordance with the Beer-Lambert law. The aim of the study was to detect the colour of vegetable oils with smartphonebased image analysis.

\section{MATERIALS AND METHODS}

Colorimetric analysis with smartphone-based images was carried out at the Department of Chemistry, Faculty of Food Technology at the Latvia University of Life Sciences and Technologies.

Samples. In total, eleven unrefined vegetable oils in the original commercial packaging were selected for analysis: sea buckthorn (Hippophae rhamnoides), sunflower (Helianthus annuus), rice (Oryza sativa), macadamia nut (Macadamia integrifolia), hemp (Cannabis sativa), corn (Zea mays), grape, linseed (Oleum Lini), rapeseed (Brassica napus), olive (Olea europaea), and milk thistle (Silybum marianum) oils.

Equipment for analysis. For imaging, a smartphone Huawei P30 Lite (Huawei Technologies Co., Ltd., China) released 2019, April 25, with operating system EMUI 10 (Android 10) and a 48-megapixel triple camera was used.

Image acquisition system. The digital image acquisition system consisted of a polyvinyl chloride PULUZ photo studio (Puluz Technology Ltd., China) softbox $(24 \times 32 \times 38$ $\mathrm{cm}^{3}$ ). Constant light intensity was provided by a 40 piece light-emitting diode (LED) lamp (model 2835), with luminous flux $550 \mathrm{~lm}$, colour temperature $3200 \mathrm{~K}$ and power 3.5 W. A LED lamp was located at the upper part inside the lightbox. For taking a colorimetric image, a smartphone with a 48-megapixel camera (Huawei P30 Lite) was positioned outside in front of the open side of the box at a dis- tance of $12 \mathrm{~cm}$ from PS $2.5 \mathrm{ml}$ macro disposable cuvettes (BrandTech Scientific, Inc., US) filled with either deionised water (blank solution), vegetable oil samples of a standard solutions of iodine with a concentration range from 0 to $100 \mathrm{mg} \cdot 100 \mathrm{ml}^{-1}$.

Imaging and image analysis. Images were captured by the smartphone camera and saved as 8-bit JPG format with average size of $7.0(8000 \times 6000$ pixels $)$, ISO 400, f/1.8, 27 $\mathrm{mm}$ (wide), 1/2.01/2, $0.8 \mu \mathrm{m}$, PDAF (Phase Detection Autofocus). Images were analysed using a RGB colour model application for Android "ColourMeter", which was installed from Android Apps on Google Play store.

Colorimetric analysis by determination of colour. The colour of the vegetable oils was determined and compared with standard solutions of iodine prepared according to GOST 5477-2015 (GOST 5477, 2015).

Standard solutions of iodine. An amount of $0.260 \pm 0.001$ $\mathrm{g}$ of iodine (sublimated for analysis EMSURE® ACS, ISO, Reag. Ph Eur, Merck KGaA, Germany) was transferred into a volumetric flask with capacity $250 \mathrm{ml}$ and $100 \mathrm{ml}$ of deionised water (Crystal E HPLC System, Adrona, Latvia) was added. After all of iodine was dissolved, deionised water was added to the volumetric flask till mark, closed with a stopper and mixed. The concentration of the prepared iodine solution was tested by titration with a solution of sodium thiosulfate $\left(\mathrm{Na}_{2} \mathrm{~S}_{2} \mathrm{O}_{3}=0.01 \mathrm{~mol} \cdot \mathrm{l}^{-1}\right)$ (ReagentPlus $\AA$, $99 \%$, Sigma-Aldrich, USA). Concentration of the prepared standard solution of iodine was $100 \mathrm{mg} \cdot 100 \mathrm{ml}^{-1}$.

Iodine scale. Iodine standard solution (100 mg.100 ml-1) and deionised water were added from a burette into test tubes in the amounts indicated in Table 1.

Determination of colour in vegetable oils and iodine standard solution. A blank solution, vegetable oil and iodine standard solutions were transferred to PS $2.5 \mathrm{ml}$ macro disposable cuvettes (BrandTech Scientific, Inc., US) with dimensions $12.5 \times 12.5 \times 45 \mathrm{~mm}$. Direct imaging of blank, samples or standard solutions in cuvettes was done using a smartphone-based colorimetric application by a RGB colour model, shown in Figure 1.

The obtained images from the smartphone application "Colour Picker" in RGB mode had an average colour value according to the equation previously (Jansons and Meija, 2002) with modification for the individual red $\left(R_{a v g}\right)$, green $\left(\mathrm{G}_{\mathrm{avg}}\right)$, blue $\left(\mathrm{B}_{\mathrm{avg}}\right)$, red-green red-green-blue $\left(\mathrm{RGB}_{\mathrm{avg}}\right)$ colours by equations 1 and 2 .

$$
\begin{aligned}
& R_{\text {avg }}=\frac{\sum_{i=1}^{n} R_{i}}{n} \quad G_{\text {avg }}=\frac{\sum_{i=1}^{n} G_{i}}{n} \quad B_{\text {avg }}=\frac{\sum_{i=1}^{n} B_{i}}{n} \\
& \operatorname{red}\left(\mathrm{R}_{\mathrm{avg}}\right) \quad \text { green }\left(\mathrm{G}_{\mathrm{avg}}\right) \quad \text { blue }\left(\mathrm{B}_{\mathrm{avg}}\right) \\
& R G B_{\text {avg }}=\frac{\frac{\sum_{i=1}^{n} R_{i}}{n}+\frac{\sum_{i=1}^{n} G_{i}}{n}+\frac{\sum_{i=1}^{n} B_{i}}{n}}{3} \\
& \text { red-green-blue }\left(\mathrm{RGB}_{\mathrm{avg}}\right)
\end{aligned}
$$


Table 1. Iodine standard solution for colour analysis expressed as colour number

\begin{tabular}{c|c|c|c}
\hline Test tube & $\begin{array}{c}\text { Iodine standard } \\
\text { solution } \\
\left(100 \mathrm{mg} \cdot 100 \mathrm{ml}^{-1}\right), \\
\mathrm{ml}\end{array}$ & $\begin{array}{c}\text { Deionized water, } \\
\mathrm{ml}\end{array}$ & Colour number \\
\hline 1 & 10.0 & - & 100 \\
2 & 9.0 & 1.0 & 90 \\
3 & 8.0 & 2.0 & 80 \\
4 & 7.0 & 3.0 & 70 \\
5 & 6.0 & 4.0 & 60 \\
6 & 5.0 & 5.0 & 50 \\
7 & 4.0 & 6.0 & 40 \\
8 & 3.0 & 7.0 & 30 \\
9 & 2.5 & 7.5 & 25 \\
10 & 2.0 & 8.0 & 20 \\
11 & 1.5 & 8.5 & 15 \\
12 & 1.0 & 9.0 & 10 \\
13 & 0.5 & 9.5 & 5 \\
& & &
\end{tabular}

a.

b.
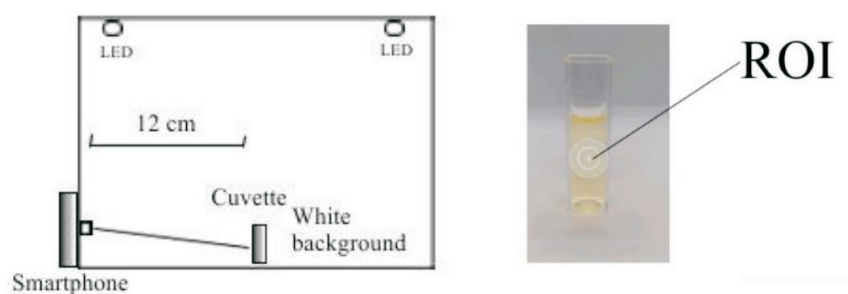

Fig. 1. (a) Illustration of photo studio lightbox experimental setup for image acquisition; (b) example of region of interest (ROI) from sample image.

The average colour value of $\mathrm{R}_{\mathrm{avg}}, \mathrm{G}_{\mathrm{avg}}, \mathrm{B}_{\mathrm{avg}}, \mathrm{RGB}_{\mathrm{avg}}$ was converted to absorbance by modified Beer-Lambert's equation 3 (Mayerhöfer et al., 2020).
$A_{\text {Iodine or vegetable oil }}=-\log \left(\frac{I_{\text {Ior veg.oil }}}{I_{0}}\right)$

where:

$\mathrm{I}_{\text {I or veg.oil }}-\mathrm{RGB}_{\text {avg }}$ average colour value of iodine standard solution or vegetable oil

$\mathrm{I}_{0}-\mathrm{RGB}_{\text {avg }}$ average colour value of the blank (deionised water).

Data processing/statistical analysis. The data was analysed by statistical and mathematical methods (mean, standard deviation). For data analysis, the Microsoft Excel software (version 2016) was used. Samples were analysed in five replicates.

\section{RESULTS}

For determination of the colour number of vegetable oils, firstly digital imaging of the iodine standard solutions was used to make a calibration curve in RGB colour mode. Results were expressed as the colour number in the range from 0 to 100 for iodine calibration solutions by intensity of Rred, G-green and B-blue colours (Fig. 2).

The greatest change of colour of iodine standard solutions occurred for the $\mathrm{G}$ and $\mathrm{B}$ calibration curves. A difference in green colour $(\mathrm{G})$ was observed between in all iodine solutions, but blue colour showed a more rapid decline in the calibration curve in the range from 5 to 40 px. Such a rapid decrease in blue pixels was due to increased intensity of yellow colour with increase of iodine concentration. Decrease in blue colour was expected, as this colour does not contribute to the formation of yellow colour, which is secondary and formed from a mixture of red and green colours. In all iodine solutions, the red colour was practically the same.

To obtain the best colorimetric detection of oil samples, intensity of red, green and blue colours of iodine standard so-

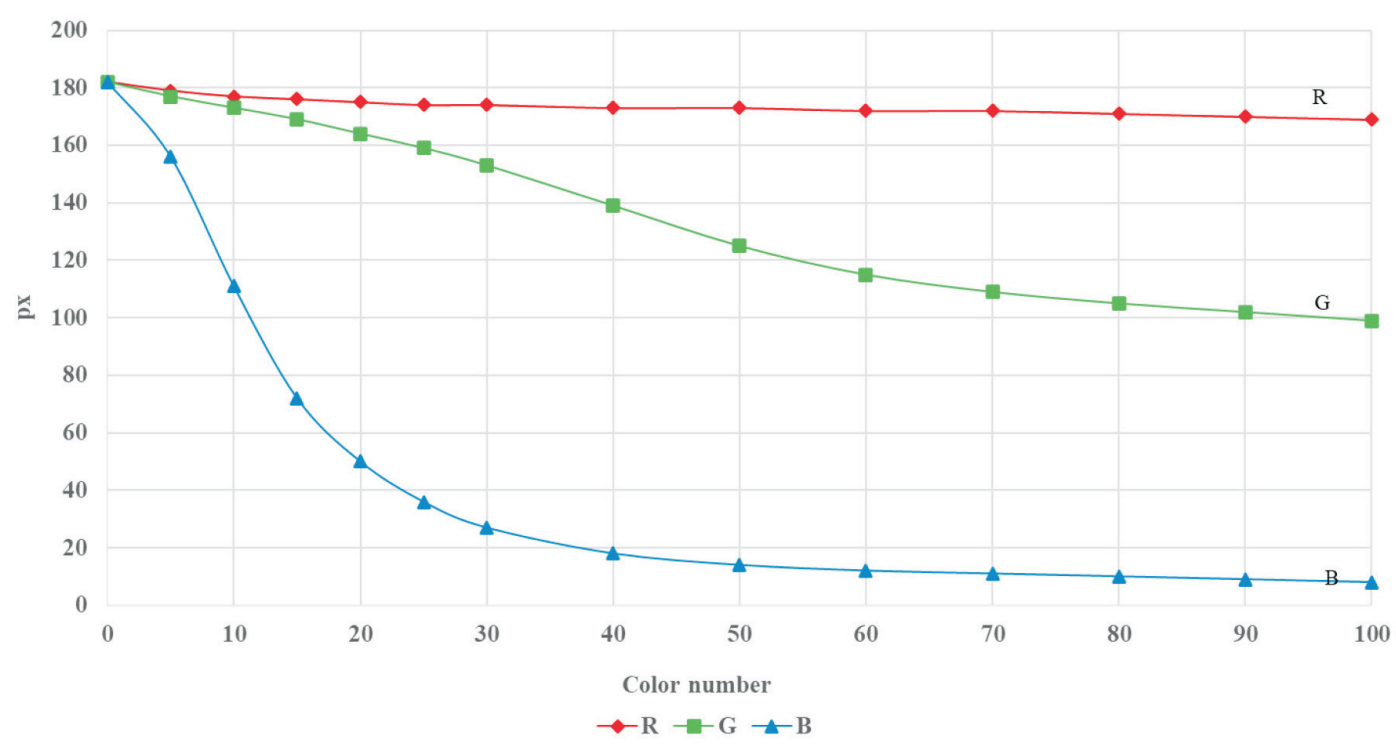

Fig. 2. RGB depends on the value of the colour number of the iodine standard solution. 


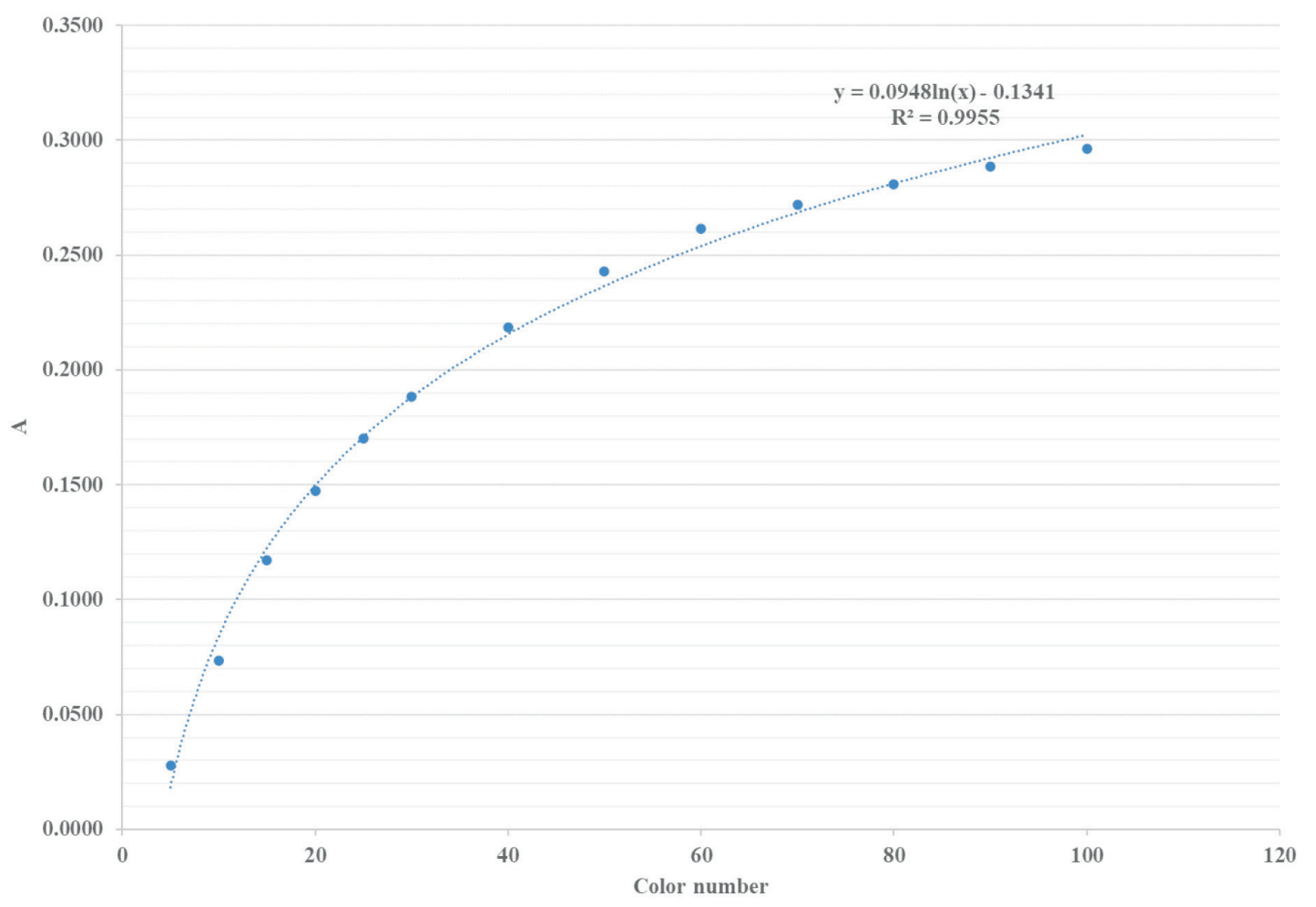

Fig. 3. Calibration curve of iodine solution with smartphone. lutions were summarised and averaged, because vegetable oils may contain not only yellow colour, but also chlorophyll-containing green pigments, such as hemp or olive oils.

The average colour value of $\mathrm{RGB}_{\text {avg }}$ was converted to absorbance using Beer-Lambert's equation 3 to calculate the calibration curve of iodine solution expressed as colour number according Table 1 (Fig. 3).

As demonstrated in Figure 3, the obtained calibration curve is nonlinear and the coefficient of determination for the iodine calibration solution was very high $\mathrm{R}^{2}=0.9955$.

The highest colour number of vegetable oil was for hemp $(46.1 \pm 0.1)$ and olive oils $(41.3 \pm 0.1)$, and lowest for linseed $(4.2 \pm 0.1)$, grape $(4.4 \pm 0.1)$, rice $(4.5 \pm 0.1)$, macadamia nut $(4.6 \pm 0.1)$, corn $(4.9 \pm 0.1)$ and sunflower $(7.4 \pm$ $0.1)$ oils. Mid-range colour numbers were found for milk thistle $(15.3 \pm 0.1)$, rapeseed $(15.7 \pm 0.1)$ and sea buckthorn $(23.3 \pm 0.1)$ oils (Fig. 4).

\section{DISCUSSION}

For colorimetrical measurement by image analysis of vegetable oils and iodine standard solutions, a smartphone with a sensor that could detect three primary red, green, and blue colours was used (Kong et al., 2019). In nature, white colour is formed from the sum of all three primary colours red $(\mathrm{R})$, green $(\mathrm{G})$, and blue (B), and therefore, white colour was used as a background in the image.

Each primary colour has pixel values in the range from 0 to 255 and white colour must be a maximum of pixels, respectively, 255 (Mather and Koch, 2005). By using a photography lightbox studio PULUZ with light-emitting diodes
(LED) it was found that it was not possible to obtain a completely white colour or 255 pixels. Using this model lightbox with a white background, 182 pixels were detected for blank solution in the RGB colour model. Decrease in the pixel range was caused by the used lightbox LED string light colour temperature $3200 \mathrm{~K}$.

According to the results, hemp and olive oils have high concentrations of plant pigments and are rich in biologic active substances like chlorophylls and carotenoids. Hemp and olive oils contain more chlorophylls than carotenoids, respectively, $138 / 2-5 \mathrm{mg} \cdot \mathrm{kg}^{-1}$ and $33.6 / 6.0 \mathrm{mg} \cdot \mathrm{kg}^{-1}$. Chlorophyll has a much darker colour that carotenoids, and therefore, a higher colour number was observed for hemp and olive oils than for the other vegetable oils (Niewiadomski et al., 1965; Oomah et al., 2002; Nikolova et al., 2012; Saastamoinen et al., 2016). Chlorophyll content of linseed, grape, rice, macadamia nut, corn, and sunflower are very low and in the range between 0.30 and $1.79 \mathrm{mg} \cdot \mathrm{kg}^{-1}$, but the carotenoid content is higher and in the range of 4.32 to $10.6 \mathrm{mg} \cdot \mathrm{kg}^{-1}$ (Robert et al., 2007; Kreps et al., 2014; Shinagawa et al., 2018). Mid-range content of chlorophylls (1.79-6.56 $\mathrm{mg} \cdot \mathrm{kg}^{-1}$ and carotenoids $5.02-9.57 \mathrm{mg} \cdot \mathrm{kg}^{-1}$ ) occur in milk thistle and rapeseed oils. Sea buckthorn oil is one of the richest carotenoid-containing vegetable oils with content exceeding $302.8 \mathrm{mg} \cdot \mathrm{kg}^{-1}$ (Tudor et al., 2019). Different colour numbers in vegetable oils depend on the quality of raw material, botanical variety and production technology.

\section{CONCLUSIONS}

In the present study, a new method based on the smartphone-based colorimetry was used for the determination of colour. The principle of this method is to analyse a digital 


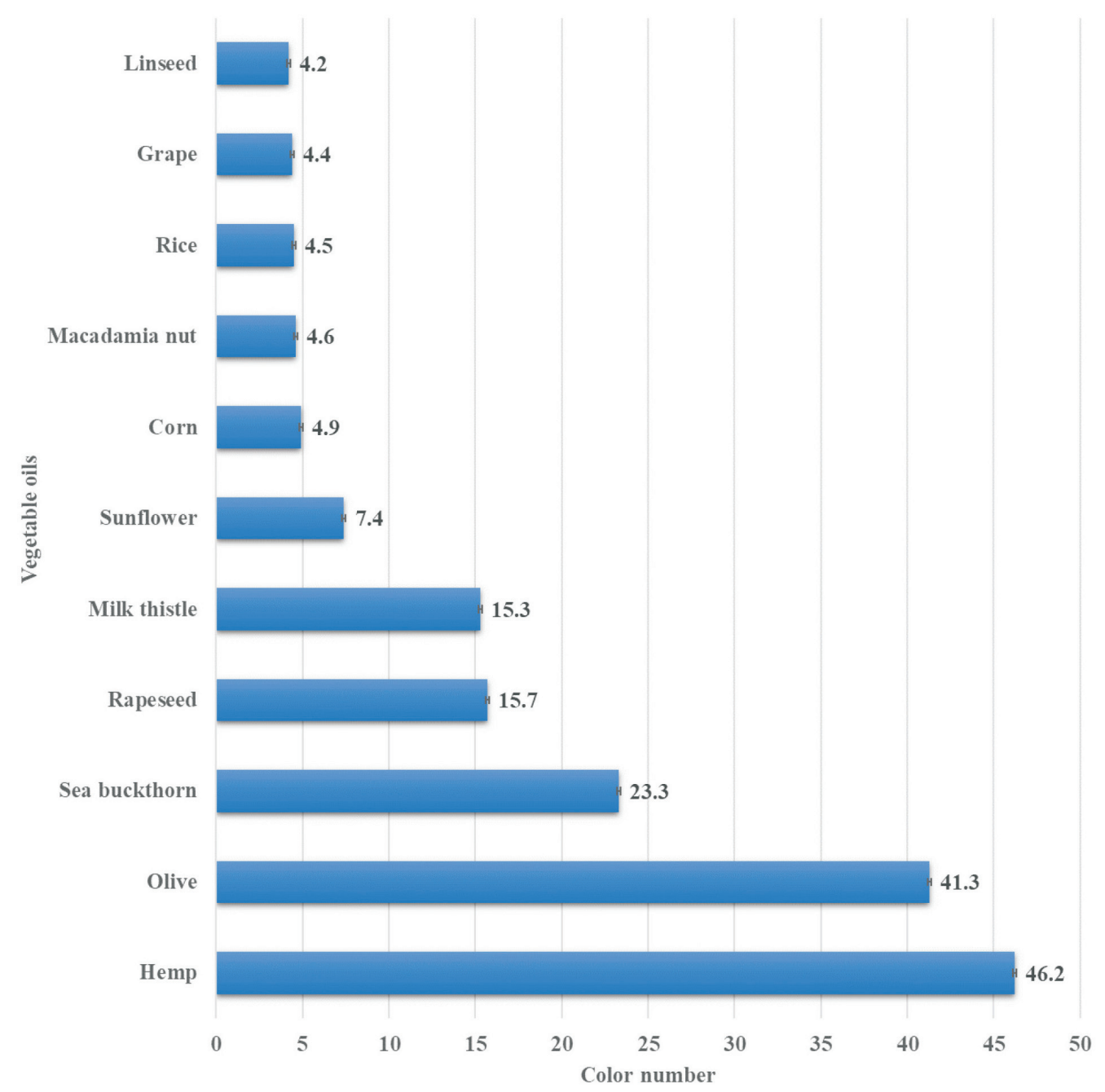

Fig. 4. Colour number of vegetable oils.

image of colour in vegetable oils compared with iodine standard solutions, which were obtained with a smartphone camera. Using the iOS application on Android for colour analysis with a RGB colour model system it was possible to convert the results to absorbance by the Beer- Lambert's Law and express the results as colour number. Smartphonebased colorimetry is simple to use, mobile, and has low cost; therefore, it is necessary to develop new detection methods for various chemical analyses based on the principle of analysis of smartphone-based digital images.

\section{ACKNOWLEDGEMENTS}

The research was supported by the Latvia University of Life Sciences and Technologies under the project "Strengthening Research Capacity in the Latvia University of Life Sciences and Technologies". Project No. 3.2-10/126, Z46.

\section{REFERENCES}

Anderson, R. J., Bendell, D. J., Groundwater, P. W. (2004). Organic Spectroscopic Analysis. $1^{\text {st }}$ edition. Royal Society of Chemistry, Cambridge. $176 \mathrm{pp}$.

Anguelova, T., Warthesen, J. (2000). Degradation of lycopene, $\beta$-carotene, and $\alpha$-carotene during lipid peroxidation. J. Food Sci., 65, 71-75.
Bueno, L., Meloni, G. N., Reddy, S. M., Paixao, T. R. L. C. (2015). Use of plastic-based analytical device, smartphone and chemometric tools to discriminate amines. RSC Advances, 26 (5), 20148-20154.

Coskun, A. F., Wong, J., Khodadadi, D., Nagi, R., Tey, A., Ozcan, A. (2013). A personalized food allergen testing platform on a cellphone. Lab Chip, 13 (4), 636-640.

Das, A. J., Wahi, A., Kothari, I., Raskar, R. (2016). Ultra-portable, wireless smartphone spectrometer for rapid, non-destructive testing of fruit ripeness. Sci. Rep., 6, 32504.

Ernster, L., Dallner, G. (1995). Biochemical, physiological and medical aspects of ubiquinone function. Biochim. Biophys. Acta, 1271 (1), 195-204.

Fakourelis, N., Lee, E. C., Min, D. B. (1987). Effects of chlorophyll and $\beta$-carotene on the oxidation stability of olive oil. J. Food Sci., 52, 234-236.

Frančáková, H., Ivanišová, E., Dráb, Š., Krajčovič, T., Tokár, M., Mareček, J., Musilová, J. (2015) Composition of fatty acids in selected vegetable oils. Potravinarstvo, 9 (1), 538-542.

Huang, H. Y., Alberg, A. J., Norkus, E. P., Hoffman, S. C., Comstock, G. W., Helzlsouer, K. J. (2003). Prospective study of antioxidant micronutrients in the blood and the risk of developing prostate cancer. Amer. J. Epidemiol., 157, 35-344.

Inanc, A. L. (2011). Chlorophyll: Structural properties, health benefits and its occurrence in virgin olive oils. Akademik Gida, 9, 26-32.

Jansons, E., Meija, J. (2002). Kḷūdas kvantitatīvajās noteikšanās [Errors of Quantitative Determinations]. Rasa ABC, Rīga. 155 lpp. (in Latvian).

Kreps, F, Vrbiková, L, Schmidt, S̆. (2014). Influence of industrial physical refining on tocopherol, chlorophyll and beta-carotene content in sunflower and rapeseed oil. Eur. J. Lipid Sci. Technol., 116 (11), 1572-1582. 
Kong, T., You, J. B., Zhang, B., Nguyen, B., Tarlan, F., Jarvi, K., Sinton, D. (2019). Accessory-free quantitative smartphone imaging of colorimetric paper-based assays. Lab on a Chip, 19 (11), 1991-1999.

Kroemer, S., Fruhauf, J., Campbell, T. M., Massone, C., Schwantzer, G., Soyer, H. P. (2011). Mobile teledermatology for skin tumour screening: diagnostic accuracy of clinical and dermoscopic image tele-evaluation using cellular phones. Brit. J. Dermatol., 164 (5), 973-979.

Levin, S., Krishnan, S., Rajkumar, S., Halery, N., Balkunde, P. (2016). Monitoring of fluoride in water samples using a smartphone. Sci. Total Environ., 551-552, 101-107.

Masawat, P., Harfield, A., Namwong, A. (2015). An iPhone-based digital image colorimeter for detecting tetracycline in milk. Food Chem., 184, $23-29$.

Mather, P. M., Koch, M. (2005). Computer Processing of Remotely-Sensed Images: An Introduction. $4^{\text {th }}$ edition. John Wiley \& Sons, Ltd, $61 \mathrm{pp}$.

Mayerhöfer, T. G., Pahlow, S., Popp, J. (2020). The Bouguer-Beer-Lambert Law: Shining Light on the Obscure. ChemPhysChem., 21, 1-19.

Moreau, R. A., Johnston, D. J., Hicks, K. B. (2007). Comparison of the levels of lutein and zeaxanthinin corn germ oil, corn fiber oil and corn kernel oil. J. Amer. Oil Chem. Soc., 84 (11), 1039-1044.

Narayana, P. S., Varalakshmi, D., Pullaiah, T. (2016). Research Methodology in Plant Science. Scientific Publishers. 388 pp.

Niewiadomski, H., Bratkowska, I., Mossakowska, E. (1965). Content of chlorophylls and carotenes in rapeseed oil. J. Amer. Oil Chem. Soc., 42, $731-734$.

Nikolova, K., Eftimov, T., Perifanova, M., Brabant, D. (2012). Quick fluorescence method for the distinguishing of vegetable oils. J. Food Sci. Eng., 2, 674-684.

Oomah, B. D., Bussonb, M., Godfreya, D. V., Drovera, J. C. G. (2002). Characteristics of hemp (Cannabis sativa L.) seed oil. Food Chem., 76 (1), $33-43$.

Ozcan, A., Coskun, A., Wong, J. (2013). Allergen Testing Platform for Use with Mobile Electronic Devices. 14/053,475. U.S. Patent and Trademark Office.

Pareek, S., Sagar, S. P., Sharma, S., Kumar, V., Agarwal, T., GonzálezAguilar, G. A., Yahia, E. M. (2017). Chlorophylls: Chemistry and biological functions. In: Fruit and Vegetable Phytochemicals: Chemistry and Human Health. $2^{\text {nd }}$ edition. Wiley-Blackwell, John Wiley \& Sons Ltd., pp. 269-284.

Received 22 March 2021

Accepted in the final form 22 November 2021
Prakash, D., Gupta, C. (2014). Carotenoids: Chemistry and health benefits. In: Phytochemicals of Nutraceutical Importance. CAB International, pp. 181-195.

Rhyne, T. M. (2016). Applying Color Theory to Digital Media and Visualization. CRC Press, Boca Raton. 112 pp.

Roda, A., Michelini, E., Zangheri, M., Di Fusco, M., Calabria, D., Simoni, P. (2016). Smartphone-based biosensors: A critical review and perspectives. TrAC Trends in Analytical Chemistry, 79, 317-325.

Saastamoinen, M., Eurola, M., Hietaniemi V. (2016). Oil, protein, chlorophyll, cadmium and lead contents of seeds in oil and fiber flax (Linum usitatissimum L.) cultivars and in oil hemp (Cannabis sativa L.) cultivar Finola cultivated in South-Western part of Finland. J. Food Chem. Nanotechnol., 2 (2), 73-76.

Shinagawa, F. B., de Santana, F.C., Araujo, E., Purgatto, E., Mancini-Filho, J. (2018). Chemical composition of cold pressed Brazilian grape seed oil. Food Sci. Technol., 38 (1), 164-171.

Tudor, C., Bohn T., Iddir, M., Dulf, F. V., Focsan, M., Ruginć, D. O., Pintea A. (2019). Sea buckthorn oil as a valuable source of bioaccessible xanthophylls. Nutrients, 12 (1), 76.

Vashist, S. K., Luong, J. H. T. (2019). Point-of-Care Technologies Enabling Next-Generation Healthcare Monitoring and Management. Springer Nature Switzerland AG, 232 pp.

Vucane, S., Sabovics, M. Leitans, L., Cinkmanis, I. (2020). Smartphonebased colorimetric determination of DPPH free radical scavenging activity in vegetable oils. Research for Rural Development 2020: Annual $26^{\text {th }}$ International Scientific Conference Proceedings, Jelgava, Latvia, 13-15 May, Latvia University of Life Sciences and Technologies. Jelgava, Vol. 35, pp. 106-111.

Yetisen, A. K., Martinez-Hurtadoa, J. L., Garcia-Melendrez, A., da Cruz Vasconcellosa, F., Lowea, C. R. (2014). A smartphone algorithm with inter-phone repeatability for the analysis of colorimetric tests. Sensors and Actuators B: Chem., 196, 156-160.

Zhang, D., Liu, Q. (2016). Biosensors and bioelectronics on smartphone for portable biochemical detection. Biosensors Bioelectron., 75, 273-284.

Zhu, H., Sikora, U., Ozcan, A. (2012). Quantum dot enabled detection of Escherichia coli using a cell-phone. The Analyst, 137 (11), 2541-2544.

Zhu, H., Yaglidere, O., Su, T., Tseng, D., Ozcan, A. (2011). Cost-effective and compact wide-field fluorescent imaging on cell phone. Lab Chip, 11 (2), 315-322.

\section{AUGU EL,ḶU KOLORIMETRISKIE MĒRĪJUMI AR VIEDTĀLRUNİ BĀZĒTU ATTĒLU ANALĪZI}

Augu eḷıu krāsas kolorimetriskai noteikšanai tika izmantots Huawei P30 lite viedtālrunis un Android lietojumprogramma "Color Picker" ar RGB modela algoritmu (R-sarkans, G-zalš un B-zils). Paraugu un standarta škīiumu attēls tika uznemts polivinilhlorīda kastē ar gaismas diožu (LED) spuldzēm. Pētījuma mērķis bija noteikt augu eḷıu krāsu, izmantojot viedtālrunī balstītu attēlu analīzi. Vienpadsmit augu ellıu — smiltsērkšḳu, saulespuku, rīsu, makadāmijas riekstu, kanepju, kukurūzas, vīnogu, linsēklu, rapšu, olīvu un mārdadžu krāsas tika salīdzinātas ar joda standartškīdumiem, kuru koncentrācija bija robežās no 0 līdz $100 \mathrm{mg} \cdot 100 \mathrm{ml}^{-1}$. Ar viedtālruni uzṇemtais RGB modelis ir vērtību diapazonā no 0 līdz 255. Rezultāti parādīja, ka augu eḷlu krāsas noteikšanai var izmantot kolorimetriju, kuras pamatā ir viedtālrunis, un to ir iespējams salīdzināt ar standarta joda šḳīdumiem. Augu eḷlu krāsa tika izteikta kā krāsas skaitlis, kas iegūts no joda standartškīiduma, kas sagatavots dejonizētā ūdenī. 